樣にも思えるが，この実験の結果げけからでは判定する ことができない，との曲線で 5 秒近辺で各元素各試料と も多かれ少かれ極大を示している事はあらゆる点から予 備放電 5 秒で測定する事が適当でない事を示している. 実際に標淮武料, 分析試料の両者共に予備放電 15 秒と して測定した結果上に述べた雪が明らかに判明した。 Fig. 6 にこの結果が示してあるが，予備放電 5 秒の場合 の Fig.2(C)に比較して各元素ともその直径 $6 \mathrm{~mm}$ 以下 に於ける分析值の增加が著しく減少している事がわかつ た. 更に又分析可能な範国子発光条件 3 の場合には直径 $6 \mathrm{~mm}$ 以上あれば充分である事がわかつた。

\section{5. 結言}

今まで述べて来た種々の実験の結果, 直径 $13 \mathrm{~mm} の$ 標淮試料を使用し, 発光条件 1,3 , 予備放電時間 5 秒
とした場合は棒状試料の分析可能な直径は $8 \mathrm{~mm}$ 以上と なる. 発光条件 3 , 予備放電時間15秒にとつた場合, 分 析可能な直径は $6 \mathrm{~mm}$ 以上となる．唄つた分析值を生ず るスペクトクル線の強度変化の原因としては使用したス ペクトル線の自己吸収，金属原子の蒸発速度の差異だと 考えられる.前者は放電面の形状で著しく変化し, 後者 は試料の温度, 試料の金属学的状態, 湘定元素等に関係 しているあのと思われる。しかしとれらの原因を明らか にするためには今後更に検討を重ねなければならない。

最後にこの実験を行らに当つて試験試料を提供された 池内精工株式会社, 東京製網株式会社研究所に対して厚 く感謝する。

\section{交献}

(1) 小田：電気化学 11, （昭18）

（2）武井：日本金属学会分科会報告 第 XIII 輯

\title{
フレームホトメーターによる各種高炉原料 及び副生成物中のアルカリ定量について
}

(昭和 31 年 3 月 13 日受理)

石田良平* ・藤代芳正 ${ }^{*} \cdot$ 真中隼 $太^{* *}$ 橋本勇二郎** 金 子 弘 徳 ${ }^{* *}$

Flame Photometric Determination of Alkali Elements in Raw Materials and By-product of Blast Furnace Ryohei ISHIDA*, Yoshimasa FUJISHIRO*, Hayata MANAKA** Yujiro HASHIMOTO ${ }^{k *}$ and Hironori KANEKO**

Description is given of the operating conditions of Perkin-Elmer Flamephotometer 52 C-type in both of internal standard method and direct method. The highest precision and accuracy are obtained with optimum pressures of about 1.2 and 2 atm. for acetylene gas and compressed air respectively and with the concentration range of solution between 20 and $70 \mathrm{ppm}$ for each elements. In this method two operators have worked out about 700 samples in one month. In comparing these results with those of Lange's Flamephotometer, good agreements are obtained.

\section{1. 緒言}

高炉に使用する鉱石原料及びその生成物である高滓， 高炉灰中のアルカリが問題となり，これを梌討するため 多数のそれ等陚料中のデルカを短期間に分析する必要 に迫られた。これに対して，従来行つてきた重量法は非
常に手数がかかり，とのため長い時間と高度の熱練を要

*工業技術院果京工業試験所

**日本鋼管株式会社技術研究所

*Government Chemical Industrial Research Institute, Tokyo.

**Technical Research Laboratory, Nippon Kokan $\mathrm{K} . \mathrm{K}$. 
し, 僅か数本の陚料に数日るかかると云う状態である。 依つてその解決策として炎光法を採用する事になつた。 この結果操作も簡単で精度もよく, 非常な成果をあげた ので, その径過に就いて報告する。

\section{2. 裝置及び標舫溶液}

\section{1. 装置}

(1) パーキンェルマー 52-C型

檋造の略図は Fig.1 の如くでをる.

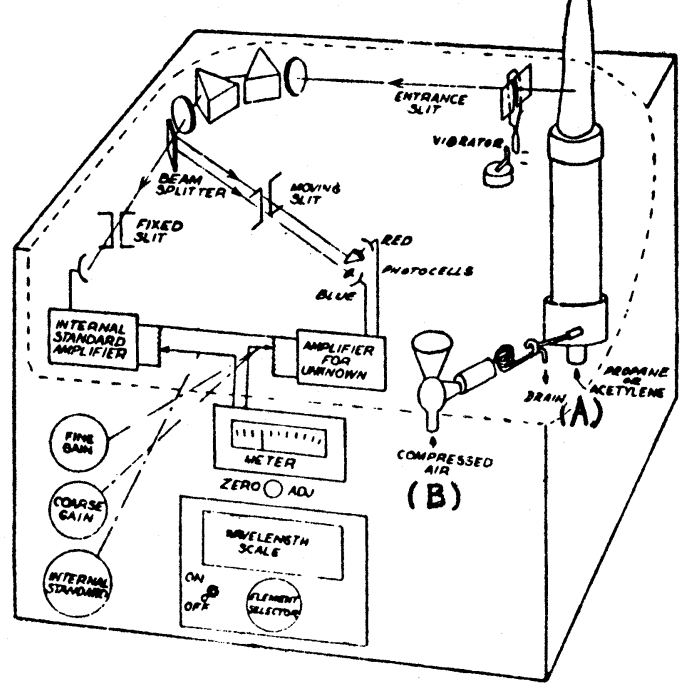

Fig.1 Schematic diagram of Perkin-Elmer 52-C type flamephotometer.

(2) 压力計

空気及び然料の流圧を一定にして光源の安定を計るた め, 圧力計を必要とする。筆者等は東工試で武作した Fig. 2 の加きるのを用いた。

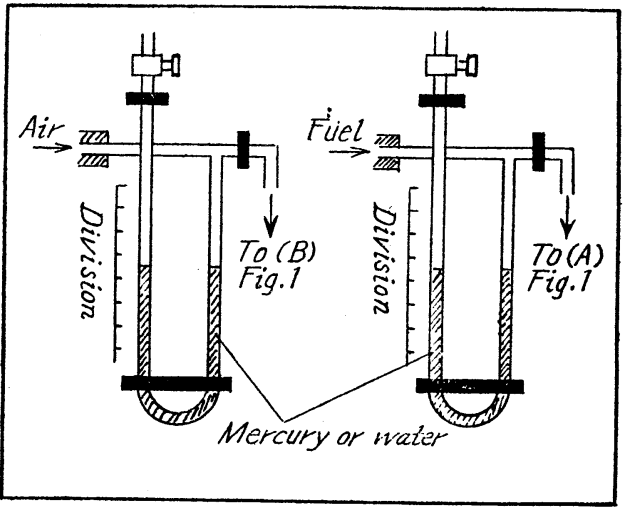

Fig. 2 Gauge for pressure of acethylene gas and compressed air.
（3）然料

然料は本装置ではアセチレン，ブロパンの耐者を用い る事が出来るが，アセチレンの方が良い結果を得ている ので，アセチレンを使用した。

\section{2. 標準溶液の調整}

再結法で精製した塩化カリウム, 塩化ナトリウム及び 炭酸リチウムを使用して標潐溶液を淍製した。

先ずカリウム, ナトリウム, リチムムの备元素の1000 乃至 $10000 \mathrm{ppm}$ の濃度のものを作り，てれを貯蔵液と する。この貯蔵液の各一定量を取り，100，70，50，20， 10,0 ppm. (何れるりチウム $50 \mathrm{ppm}$. 含有) の標淮溶液 を調製した。

添加するリチゥムの量に就いては，測定元素の濃度に 近づける事が必要であるが，高濃度の测定元素に対して 低濃度のリチゥム, 或はこの逆の場合る電気的にはバラ ンスさせるととが可能である。

パーキンェルマー製のフレームホトメーターで測定す るための最適濃度範囲は, 器械の構造主として感度の関 係から,ナトリゥム, カリゥムの各単体として $100 \mathrm{ppm}$.

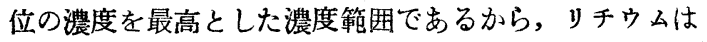
その中間の $50 \mathrm{ppm}$. 濃度のものとした。

\section{3. 炎光の基礎的条件の検討}

一般に機器による分析は，購入後直さに使用出来る事 は少く, 調整や定量条件の確立にかなりの日時を費し, 場合によつては半年以上る検討を必要とする。而しとの 実験に使用した東工試のバーキンェルマーのフレームホ ートメーターは, 既に種々の過程を径て, 極めて順調に 作動していたので，炎光の基礎的条件の検討，即らガス 圧, 空気圧及び最適濃度笨围の決定, 或いは検量線の作 成なども再確認する程度の簡単な実験で去分目的を達す るととが井来た。矢の径過を次に述べる。

\section{1. ガス压・空気圧の決定}

ガス圧, 空気圧に就いては, Fig. 3 の加く, 即ちカリ ウム又はナトリウムの一定量を取り，空気圧を一定にし て，ガス压を贸化させると，カリウムは 1.20 , ナトリウ ムは 1.27 気圧で最高の感度を示す。

空気圧はガス圧を一定にして, 遂次変化させると, 直 線的にスぺクトル線の強度を増大する。この実験から空 気压は 2.0 気圧，然料圧はカリゥム 1.20 ，ナトリム 1.27 気压を用いて Fig. 2 の圧力計で一定に保持した。

\section{2. 検悬竭の作成}

使用したパーキンェルマーフレームオトメーターは， 検出元素の放射強度を直接に测る直接強度法と, 放躬強 
16

度の比を测る内部標準法の 2 樣の测定法が出来る長所を もつている.

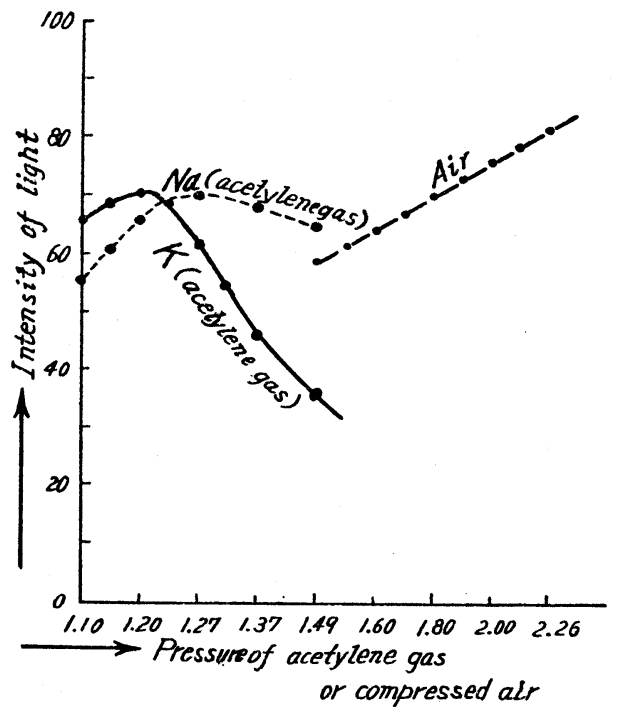

Fig. 3 Condition for pressure of acethylene gas and compressed air.

（1）直接強度法による検量線

直接強度法は被検武料中の求める元素のスペクトル線 の強度をメーターで直接読み取る方法であるから，操作 は簡単であるが，然し炎が一定で安定した光源である事 を前提としている．従つて噴霧室の空気圧の奖化や，部 分的な閉塞が起つたり，炎の状態き温度に影響を及ぼす ガス圧に変化があつたりして，噴霧や発光の条件が変化 すれば誤差を生ずる。このため精度は試料中の元素量の 約土 $3 \%$ ぞまりになる．其の上淔接強度法による検量線 によつて実際試料を浿定した場合，標準溶液にない他の 塩，酸，イォン又は有機物が存在していると，相当に励 起条件に影響してくるので，その誤差は $3 \%$ 以上になる 可能性も多い。而し高度の精度を要求しない場合や，迅 速を心要とする時には極めて有利でもり, 䀼度範䧃の未 知の際に濃度を決めたり，定性的な検出の時には非常に 役立つ方法である。

直接強度法による検量線の作成は，先ず空気圧，ガス 圧を最適の条件に保持してて，湘定元素に応じた固有の波 長目盛を確実に選定し，カリウム及びナトリウムの $0 \mathrm{ppm}$ (リチゥム $50 \mathrm{ppm}$. 含有) 標潗液で零点を調節し た後，カリウム及びナトリウムの $100 \mathrm{ppm}$. (ソチウム $50 \mathrm{ppm}$.含有) 標隻液で，増幅がインにより最大目盛100 に調節する.次に各湿度の標淮液で中間の濃度と讜みと の関係を記録し，Fig.4 の如き検量線を得た。
分 光 研 究 第 4 巻・第 3 号 (1956)

（2）内部標準法による検量線

内部標淮法は，一定量のリチゥム（内部標淮元素とし て）の入つた標淮溶液を使用して，との一定量のリチウ ムの出すスペクトル線の強度と, 標準溶液の出すスペク トル線の強度の比を湘つて震度を決定する方法である。 ての方法によればリチゥムと測定元素が同じ噴霧室中 で，同じ空気压で噴霧され，同じ炎で励起されるので， 発光に影響する条件は，両元素に同時に影響を及ぼして いるわけである，従つて空気压，ガス圧の変化は勿論， 末知試料中に含まれる他種イオンや分子等も直接法の時 よりは影響が少くなり，一回の測定の平均誤差は約 $1 \%$ であるといわれている。

内部標潐法の検量線作成法は，直接法と同樣にして, 先ず測定元素に応じたガス压，空気压，波長目盛を確実

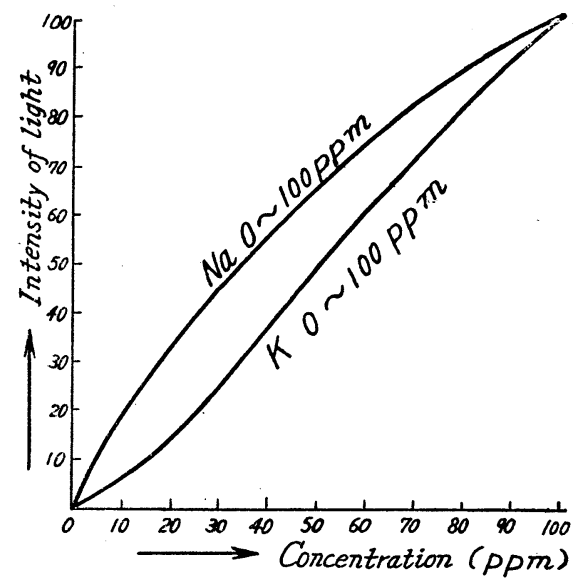

Fig. 4 Working curve for direct method.

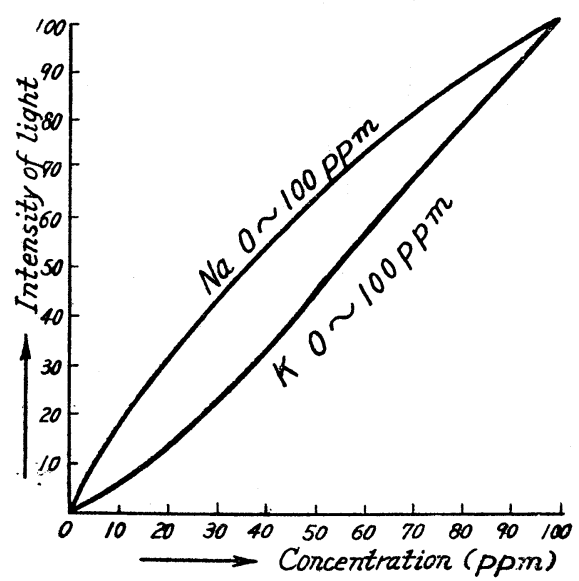

Fig.5 Working curve for internal standard method. 
に選定して，次に $0 \mathrm{ppm}$. (50 ppm. リチウム含有)を噴 霧させて内部標準用ダイアルを零にして，零点調整ダイ アルで, 50 目盛に合せる.次に $100 \mathrm{ppm}(50 \mathrm{ppm}$ リチ ウム含有)を入れて，内部標淮用ダイアルを100にし て，堌幅度ゲインにより 50 目盛に調節する。これを数 回繰返した後中閒の標潐液を励起させて，内部標準用ダ イフルを迥して，50 目盛に正しく合せる．その時の内 部標準用ダイアルの読夕を記録し Fig. 5 の如き検量線を
得た。

\section{3. 内部檽集法及び黾接強度法の重量法に 対する偑差}

湘定元素の含有量に刘して，太部標準法は約士 $1 \%$ ， 直接強度法では約土 $3 \%$ の精度であると言われているが 1例として硝子中のアルカリを重量法で定量して，ての 值と炎光法による二方法との結果を此較した。その結果 は Table 1，2 の如くでまる.

Table 1 Determination of potassium in glass.

\begin{tabular}{|c|c|c|c|c|c|c|c|}
\hline \multirow{2}{*}{ No. } & \multirow{2}{*}{ Grav. method } & \multicolumn{3}{|c|}{ Internal Standard Method } & \multicolumn{3}{|c|}{ Direct Method } \\
\hline & & $\begin{array}{c}\text { Measured } \\
\text { value }\end{array}$ & Deviation & $\%$ Deviation & $\begin{array}{c}\text { Measured } \\
\text { value }\end{array}$ & Deviation & $\%$ Deviation \\
\hline \multirow{2}{*}{1} & \multirow{2}{*}{0.32} & 0.36 & +0.04 & $(12.5)$ & 0.37 & +0.05 & $(15.6)$ \\
\hline & & 0.39 & +0.07 & $(21.8)$ & 0.39 & +0.07 & $(21.8)$ \\
\hline \multirow{2}{*}{2} & \multirow{2}{*}{0.42} & 0.42 & 0 & 0 & 0.41 & -0.01 & 2.4 \\
\hline & & 0.41 & -0.01 & 2.4 & 0.41 & -0.01 & 2.4 \\
\hline \multirow{2}{*}{3} & \multirow{2}{*}{0.51} & 0.52 & +0.01 & 2.0 & 0.52 & +0.01 & 2.0 \\
\hline & & 0.52 & +0.01 & 2.0 & 0.54 & +0.03 & 5.9 \\
\hline \multirow{2}{*}{4} & \multirow{2}{*}{3.25} & 3.25 & 0 & $\mathbf{0}$ & 3.36 & +0.11 & 3.4 \\
\hline & & 3.25 & $\mathbf{0}$ & $\mathbf{0}$ & 3.40 & +0.15 & 4.6 \\
\hline \multirow{2}{*}{5} & \multirow{2}{*}{8.40} & 8.23 & -0.17 & 2.0 & 8.34 & -0.06 & 0.7 \\
\hline & & 8.32 & -0.08 & 1.0 & 8.32 & -0.08 & 1.0 \\
\hline \multicolumn{2}{|c|}{ Mean Value } & & & 1.18 & & & 2.80 \\
\hline
\end{tabular}

Table.2 Determination of sodium glass

\begin{tabular}{|c|c|c|c|c|c|c|c|}
\hline \multirow{2}{*}{ No. } & \multirow{2}{*}{ Grav. method } & \multicolumn{3}{|c|}{ Internal Standard Method } & \multicolumn{3}{|c|}{ Direct Method } \\
\hline & & $\begin{array}{c}\text { Measured } \\
\text { value }\end{array}$ & Deviation & $\%$ Deviation & $\begin{array}{c}\text { Measured } \\
\text { value }\end{array}$ & Deviation & $\%$ Deviation \\
\hline \multirow{2}{*}{1} & \multirow{2}{*}{5.70} & 5.66 & $-\quad 0.04$ & 0.70 & 5.79 & $+\quad 0.09$ & 1.58 \\
\hline & & 5.66 & -0.04 & 0.70 & 6.00 & +0.30 & 5.26 \\
\hline \multirow{2}{*}{2} & \multirow{2}{*}{8.48} & 8.36 & -0.12 & 1.41 & 8.10 & -0.38 & 4.80 \\
\hline & & 8.49 & +0.01 & 0,12 & 8.49 & +0.01 & 0.12 \\
\hline \multirow{2}{*}{3} & \multirow{2}{*}{13.21} & 13.30 & +0.09 & 0.62 & 13.20 & -0.01 & 0.08 \\
\hline & & 13.51 & +0.30 & 2.27 & 13.48 & $+\quad 0.27$ & 2.04 \\
\hline \multirow{2}{*}{4} & \multirow{2}{*}{13.66} & 13.78 & +0.12 & 0.88 & 13.70 & +0.04 & 0.29 \\
\hline & & 13.78 & +0.12 & 0.88 & 13.90 & +0.24 & 1.76 \\
\hline \multirow{2}{*}{5} & \multirow{2}{*}{13.82} & 13.88 & +0.06 & 0.43 & 13.78 & -0.04 & 0.29 \\
\hline & & 13.95 & +0.13 & 0.94 & 13.74 & -0.08 & 0.58 \\
\hline \multicolumn{2}{|c|}{ Mean Value } & & & 0.90 & & & 1.68 \\
\hline
\end{tabular}




\section{4. 実際試料に就いての試料処理方法の検討}

今回検討の刘象になつた試料は，高䐠，高炉灰及び内
地産某鉣石の筑結錴で，之れ等の含有成分の定性分光分 析の絬果は Table 3 の加くである。

既にいろいろの報告で諭ぜられているととであるが，

Table 3 Qualitative spectrographic analysis of some samples.

\begin{tabular}{|c|c|c|c|c|c|c|c|c|c|c|c|c|c|c|c|c|c|c|c|c|c|}
\hline Sample Element & $\mathrm{As}^{\prime}$ & B & $\mathrm{Si}$ & $\mathrm{Mg}$ & $\mathrm{Mn}$ & $\mathrm{Sn}$ & $\mathrm{Al}$ & Mo & V & $\mathrm{Cu}$ & $\mathrm{Na}$ & $\mathrm{Zn}$ & $\mathrm{Ti}$ & $\mathrm{Ag}$ & $\mathrm{Ni}$ & $\mathrm{Cr}$ & $\mathrm{Pb}$ & $\mathbf{K}$ & $\mathrm{Ca}$ & $\mathrm{Ba}$ & $\mathrm{Fe}$ \\
\hline Blast furnace clug & - & + & H & $H$ & $H$ & - & $\mathrm{HH}$ & - & + & + & $H$ & - & $H$ & - & - & + & - & $H$ & 曲 & + & + \\
\hline Blast furnace dust & - & $\operatorname{tr}$ & $H$ & $H$ & $H$ & + & 世 & - & + & $H$ & $H$ & $H$ & + & + & $\operatorname{tr}$ & + & $H$ & $H$ & $\mathrm{HH}$ & + & $H$ \\
\hline Sintering ore & $\operatorname{tr}$ & - & $H$ & $H$ & + & + & $H$ & $\operatorname{tr}$ & + & $H$ & $H$ & + & $H$ & $\operatorname{tr}$ & $\operatorname{tr}$ & + & + & H & H & $\operatorname{tr}$ & HH \\
\hline
\end{tabular}

試料を酸で溶解又は抽出したりする場合，酸の濃度が炎 光輝度に非常に影響するので，最終濃度は出来るだけ， 小さくしなければならない，一般に過塩素酸が最る明る い炎を与え，次は塩酸であるが遊離塩酸の濃度が，0.1 程度より濃くなると媈度が急に減少してくるととが知ら れている.硫酸や燐酸もこの存在により輝度がかなり さくなることが明らかにされている. 又共存する諸元素 の影響は Table 4 に揭げる程度とされているが，特にナ トリゥムに対するカルシウムの影饗はかなり大きい(ら (い). 從つて炎光法に於ける 定量では操作は比較的簡 単であつても，試料の如何によつて，其の分解処理法が 重要な役割を演じ，結果に及ぼす影響す複雑である。

殊に今回の高滓, 高炉灰等に至つては其の組成が, Table 3 のよらなかなり複雑であるから, 前処理は慎重 に行つた。

Table 4 Interference in acetylene flame. (As concentration of unkrown element corresponding to $1000 \mathrm{ppm}$ of interfering element.)

\begin{tabular}{c|ccccccccc}
\hline $\begin{array}{c}\text { Interfering } \\
\text { element }\end{array}$ & $\mathrm{K}$ & $\mathrm{Li}$ & $\mathrm{Na}$ & $\mathrm{Mn}$ & $\mathrm{Sr}$ & $\mathrm{Ba}$ & $\mathrm{Ca}$ & $\mathrm{Cr}$ & $\mathrm{Mg}$ \\
$\begin{array}{c}\text { Unknown } \\
\text { element }\end{array}$ & & & & & & & & & \\
\hline $\mathrm{K}$ & 1000 & 2 & 1 & 5 & 2 & 8 & 3 & 3 & 6 \\
$\mathrm{Li}$ & 1 & 1000 & 0 & 0 & 70 & 1 & 4 & 1 & 0 \\
$\mathrm{Na}$ & 1 & 3 & 1000 & 1 & 4 & 2 & 8 & 2 & 6 \\
$\mathrm{Mn}$ & 200 & 10 & 30 & 1000 & 0 & 0 & 0 & 20 & 10 \\
$\mathrm{Sr}$ & 5 & 3 & 8 & 2 & 1000 & 10 & 4 & 20 & 1 \\
$\mathrm{Ba}$ & 60 & 200 & 500 & 300 & 200 & 1000 & 25000 & 700 & 100 \\
$\mathrm{Ca}$ & 0 & 6 & 10 & 6 & 5 & 3 & 1000 & 50 & 6 \\
$\mathrm{Cr}$ & 30 & 20 & 60 & 0 & 0 & 0 & 2000 & 1000 & 0 \\
$\mathrm{Mg}$ & 60 & 60 & 200 & 60 & 80 & & 200 & 40 & 1000 \\
\hline
\end{tabular}

次に々れぞれの試料に適应した溶解処理方法を検討し て，その最適の方法を見出す事にした。

\section{1. 高漳試料処理方法の㰸討}

高滓の試料処理方法として, 次の 4 方法を試みた。 第一法 $\frac{\text { 試料 } 0.5 \mathrm{~g}}{\text { 白金皿に }}-\frac{\text { 加 熱 溶 解 }}{\mathrm{HCl} 10 \mathrm{cc}+\mathrm{H}_{2} \mathrm{O}}-\frac{\text { 乾固 }}{\text { 蒸発 }}$-放冷

溶 $\frac{\text { 解 }}{\text { Cl 1 } 1 \text { 滴 }+\mathrm{H}_{2} \mathrm{O}}-\frac{\text { 炉 過 洗 滌 }}{100 \mathrm{cc} \text { メフラスコに }}-\mathrm{Li}(1 \%) 0.5 \mathrm{cc}$ 添加一放冷一標線迄稀䣋

第二法陚料 $2.0 \mathrm{~g}-\frac{\text { 加 熱 溶 解 }}{\text { 白金血に }}-\frac{\text { 乾固 }}{\mathrm{HCl} 15 \mathrm{cc}+\mathrm{H}_{2} \mathrm{O}}$ 蒸発

溶 解 - 洗 搌生成 $\mathrm{HCl} 3$ 滴 $+\mathrm{H}_{2} \mathrm{O}-\frac{\mathrm{NH}_{4} \mathrm{OH}+\left(\mathrm{NH}_{4}\right)_{2} \mathrm{C}_{2} \mathrm{O}_{4}}{\mathrm{O}}-\frac{\mathrm{C}}{\mathrm{S}_{3}}$ フラスコー Li 2.5cc添加一標線迄稀䣋— $100 \mathrm{cc}$ 分取 す $-\mathrm{Li} 2.5 \mathrm{cc}$ 添加一 $\mathrm{H}_{2} \mathrm{O} \tau_{\mathrm{i}}$ 舅過

一測定一計算

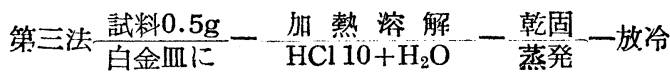
溶解 - 沈 澱生成

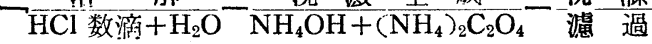

Table 5 Determination of potassium and sodium in blast furnace slug.

\begin{tabular}{|c|c|c|c|c|c|}
\hline \multirow{2}{*}{ Method } & \multirow{2}{*}{ No. } & \multicolumn{2}{|c|}{$\mathrm{K}$} & \multicolumn{2}{|c|}{$\mathrm{Na}$} \\
\hline & & ppm. & $\%$ & ppm. & $\%$ \\
\hline \multirow{4}{*}{$\begin{array}{l}\text { Int. stand } \\
\text { method }\end{array}$} & No 1 & 41.0 & 0.82 & 22.0 & 0.44 \\
\hline & No 2 & 36.0 & 0.90 & 17.0 & 0.43 \\
\hline & No 3 & 42.0 & 0.84 & 21.5 & 0.43 \\
\hline & No 4 & 34.0 & 0.68 & 6.0 & 0.12 \\
\hline \multirow{4}{*}{$\begin{array}{l}\text { Direct } \\
\text { Method }\end{array}$} & No 1 & 43.0 & 0.86 & 24.0 & 0.48 \\
\hline & No 2 & 35.0 & 0.88 & 15.0 & 0.39 \\
\hline & No 3 & 42.5 & 0.85 & 21.5 & 0.43 \\
\hline & No 4 & 33.0 & 0.66 & 5.5 & 0.11 \\
\hline \multicolumn{2}{|c|}{$\begin{array}{l}\text { Gravimetric } \\
\text { Method }\end{array}$} & & 0.82 & & 0.43 \\
\hline
\end{tabular}


分 光 研 究 第 4 巻・第 3 号 (1956)

$\mathrm{NH}_{4} \mathrm{Cl}$ 駆逐一溶 解—溜過洗涤 $\mathrm{HNO}_{3}$ で乾固 $\mathrm{HCl} 1$ 滴 $+\mathrm{H}_{2} \mathrm{O}-100 \mathrm{cc} \times ス フ ラ ス コ に$

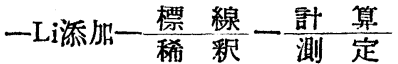

第四法試料 $0.5 \mathrm{~g}-\frac{\text { 加 熱 分 解 }}{\text { - 乾固 }}$ 放冷一 $\frac{\text { 溶 }}{\mathrm{HCl} 1 \text { 滴 }+\mathrm{H}_{2} \mathrm{O}}-\frac{\text { 濾 過 洗潗 }}{100 \mathrm{cc} \text { メスフラス }}-\mathrm{Li}$ 添加 標 線一测定一計算

以上の 4 方法の処理方法によつて分析した 結果は。

Table 5，6の如くであつた。

Table 6 Determination of potassium and sodium in blast furnace slug.

\begin{tabular}{|c|c|c|c|c|c|}
\hline \multirow{2}{*}{ Method } & \multirow{2}{*}{ No. } & \multicolumn{2}{|c|}{$\mathbf{K}$} & \multicolumn{2}{|c|}{$\mathrm{Na}$} \\
\hline & & ppm. & $\%$ & ppm & $\%$ \\
\hline \multirow{4}{*}{$\begin{array}{l}\text { Int. stand } \\
\text { method }\end{array}$} & No 1 & 49.8 & 1.00 & 25.7 & 0.51 \\
\hline & No 2 & 39.5 & 0.99 & 19.7 & 0.49 \\
\hline & No 3 & 52.7 & 1.05 & 2.70 & 0.54 \\
\hline & No 4 & 21.8 & 0.44 & 7.5 & 0.15 \\
\hline \multirow{4}{*}{$\begin{array}{l}\text { Direct } \\
\text { method }\end{array}$} & No 1 & 54.5 & 1.09 & 28.2 & 0.56 \\
\hline & No 2 & 39.2 & 0.98 & 18.4 & 0.46 \\
\hline & No 3 & 54.0 & 1.08 & 27.5 & 0.55 \\
\hline & No 4 & 21.5 & 0.43 & 7.1 & 0.14 \\
\hline \multicolumn{2}{|c|}{$\begin{array}{l}\text { Gravimetric } \\
\text { method }\end{array}$} & & 1.07 & & 0.48 \\
\hline
\end{tabular}

次に各処理法の再現性をみるため, 各操作法毎に2 Sample で処理し，其の溶液について大部標準法を用い て，測定時を変えて実験した。

其の絬果は Table 7 の通りでまつた。

Table 7 Precision of internal standard method

\begin{tabular}{|c|c|c|c|c|c|}
\hline \multirow{2}{*}{ Method } & \multirow{2}{*}{$\begin{array}{c}\text { Sample } \\
\text { No. }\end{array}$} & \multicolumn{2}{|c|}{$\mathrm{K}$} & \multicolumn{2}{|c|}{$\mathrm{Na}$} \\
\hline & & p.pm. & $\%$ & p.p.m. & $\%$ \\
\hline \multirow{4}{*}{ No. 1} & 1 & 58.7 & 1.17 & 30.0 & 0.60 \\
\hline & 2 & 58.7 & 1.17 & & \\
\hline & 1 & 57.8 & 1.16 & 31.7 & 0.63 \\
\hline & 2 & 57.8 & 1.16 & & \\
\hline \multirow{4}{*}{ No. 2} & 3 & 50.0 & 1.25 & 22.0 & 0.55 \\
\hline & 4 & 50.0 & 1.25 & & \\
\hline & 3 & 50.7 & 1.26 & 22.0 & 0.55 \\
\hline & 4 & 50.7 & 1.26 & & \\
\hline
\end{tabular}

\begin{tabular}{l|l||l|l|l|l}
\hline & 5 & 59.2 & 1.18 & 27.5 & 0.55 \\
No. 3 & 6 & 58.0 & 1.16 & & \\
\hline & 5 & 58.5 & 1.17 & 28.0 & 0.56 \\
& 6 & 58.5 & 1.17 & & \\
\hline & 7 & 57.0 & 1.14 & 18.5 & 0.37 \\
No. 4 & 8 & 57.0 & 1.14 & & \\
\hline & 7 & 56.5 & 1.13 & 21.0 & 0.42 \\
\hline $\begin{array}{c}\text { Gravimetric } \\
\text { method }\end{array}$ & 56.7 & 1.13 & & \\
\hline
\end{tabular}

以上备分解法に基づいて行つたが, 表示した重量法は， 唯一回のみの定量結果であるので，てれを標蕉值として 炎光法の結果と比較するととは稍々伦険であるが，第 4 法による偭は非常に低值を示するのが方る。これは硫酸 根の存在によるバラッキか或いは試料が完全に分解しな かつたためによるるのと思われる。

Table 7 は备方法毎に 2 sample で日を変えて行つた 定量值であるが，いずれの方法も再現性はあり，且，日 によるバラッキるとの程度ならば許されてよいと考え る.一方, 方法の差異による变動は最終検液中に共存す る他の元素の干渉に基づくるのと見られるが，第 4 法を 除けば大体満足すべき值と思われる。

以上の実験から高涬の分解方法は，第 1 ～ 3 法のいず れでもよいと思われるが，実際の使用器具 (白金皿等) の関係から, 多少時間はかかるが, ビーカーで処理出来 るので，第 3 法を用いるととにした。

少直接強度法は内部橪淮法に較べ，色々欠点があるの で，爾後の検討実験は安全を期して内部慓準法で行うこ とにした。

第 3 法の処理方法により，実際試料に就いて行い，重 量法と比較した結果の一例は次の通りでまつた。

Table 8 Comparison of method No. 3 to gravimetric method.

\begin{tabular}{c|c|c|c|c}
\hline \multirow{2}{*}{ Sample } & \multicolumn{2}{|c|}{$\mathrm{K}$} & \multicolumn{2}{c}{$\mathrm{Na}$} \\
\cline { 2 - 5 } & $\begin{array}{c}\text { Grav. } \\
\text { method }\end{array}$ & $\begin{array}{c}\text { Method } \\
\text { No.3 }\end{array}$ & $\begin{array}{c}\text { Grav. } \\
\text { method }\end{array}$ & $\begin{array}{c}\text { Method } \\
\text { No.3 }\end{array}$ \\
\hline 1 & 1.15 & $\begin{array}{l}1.18 \\
1.17\end{array}$ & 0.44 & 0.42 \\
\hline 2 & 2.34 & $\begin{array}{l}2.40 \\
2.41\end{array}$ & 0.65 & 0.65 \\
\hline
\end{tabular}

2. 高忓灰，脿結鉱試料処理方法の検討

高炉灰，焼結鉱に就いては，高㴖に準じて行つたが， ての方法では鉄が多量に存在すそため，溶解が不充分で 
あり多量の酸を必要とする。このために塩化アンモンの 生成量が多くなり，又有機物の共存る考えられるので, 前処理に要する時間は前法に較べ長くはなるが，第 5 法 として次の柡な方法を試みた。

第五法 $\frac{\text { 武料 } 0.5 \sim 1.0 \mathrm{~g}}{ヒ ゙ ー カ ー に ~}-\frac{\text { 加熱 溶 解 }}{\mathrm{HCl} 15 \mathrm{cc}+\mathrm{HNO}_{3} 5 \mathrm{cc}}$

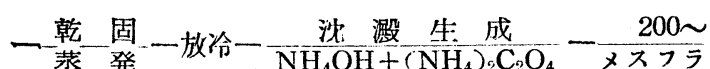

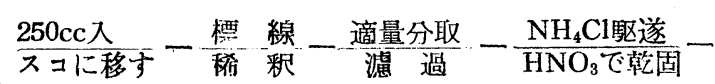

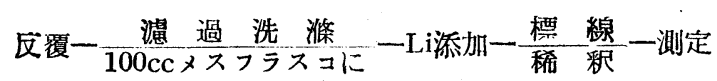
一計算
上記第 5 法と高蕉試料処理方第 $1 \sim 3$ 法とを, 高炉灭 試料について比較した結果は，次の通りであつた。

Table 9 Determination of blast dust by each decompo ition method.

\begin{tabular}{c|c|c|c|c}
\hline \multirow{2}{*}{ Method } & \multicolumn{2}{|c|}{$\mathrm{K}$} & \multicolumn{2}{c}{$\mathrm{Na}$} \\
\cline { 2 - 6 } & $\mathrm{ppm}$ & $\%$ & $\mathrm{ppm}$ & $\%$ \\
\hline No. 1 & 27.8 & 2.22 & 14.0 & 0.28 \\
\hline No. 2 & 22.5 & 2.25 & 9.0 & 0.23 \\
\hline No. 3 & 28.2 & 2.26 & 13.0 & 0.26 \\
\hline No. 5 & 27.5 & 2.20 & 11.0 & 0.22 \\
\hline
\end{tabular}

Table 10 Determination of blast furnace dust by method No. 5

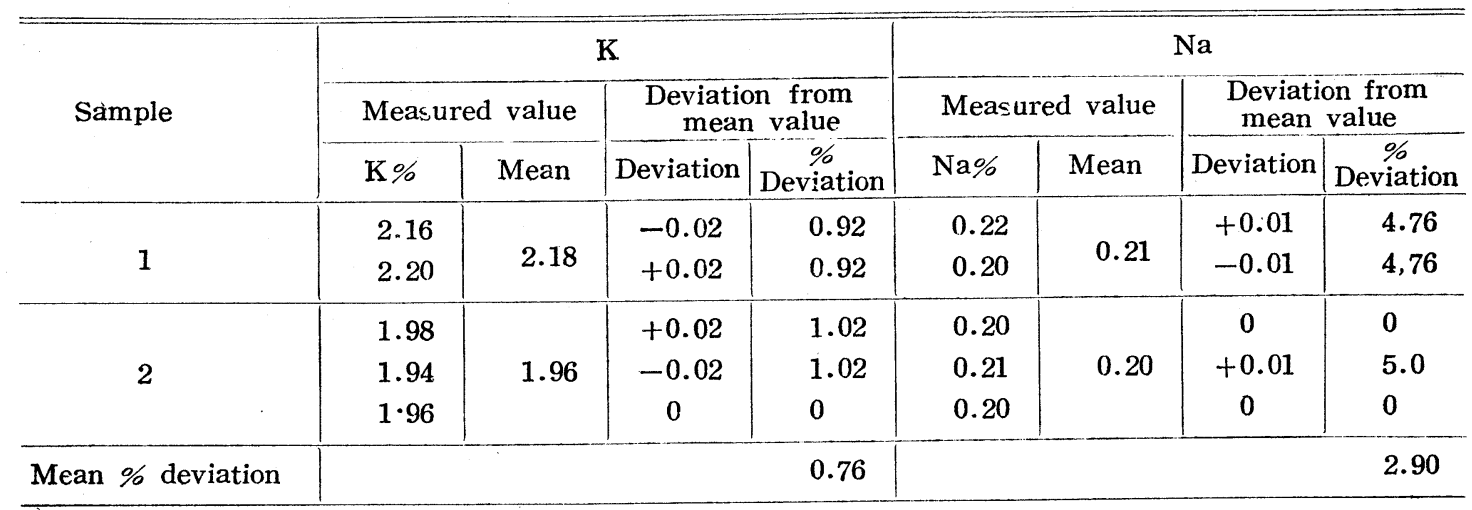

Table 11 Determination of sintering ore by method No. 5

\begin{tabular}{|c|c|c|c|c|c|c|c|c|c|}
\hline \multirow{3}{*}{ Sample No. } & \multicolumn{5}{|c|}{$\mathrm{K}$} & \multicolumn{4}{|c|}{$\mathrm{Na}$} \\
\hline & \multirow{2}{*}{\multicolumn{2}{|c|}{$\begin{array}{l}\text { Grav. } \\
\text { method }\end{array}$}} & \multicolumn{3}{|c|}{ Flame photometry } & \multirow{2}{*}{$\begin{array}{l}\text { Grav. } \\
\text { method }\end{array}$} & \multicolumn{3}{|c|}{ Flame photometry } \\
\hline & & & ppm. & $\mathrm{K} \%$ & Deviation & & ppm. & $\mathrm{Na} \%$ & Deviation \\
\hline 1 & \multicolumn{2}{|c|}{1.24} & 28.0 & 1.12 & -0.12 & 0.06 & 1.4 & 0.06 & 0 \\
\hline 2 & \multicolumn{2}{|c|}{1.01} & 25.1 & 1.00 & -0.01 & 0.03 & 1.0 & 0.04 & +0.01 \\
\hline \multirow{3}{*}{3} & \multirow{3}{*}{1.17} & a & $\begin{array}{l}56.2 \\
58.5\end{array}$ & $\begin{array}{l}1.18 \\
1.17\end{array}$ & $\begin{array}{c}+0.01 \\
0\end{array}$ & & 4.0 & 0.08 & +0.01 \\
\hline & & $\mathrm{b}$ & $\begin{array}{l}11.5 \\
11.7\end{array}$ & $\begin{array}{l}1.15 \\
1.17\end{array}$ & $\begin{array}{c}-0.02 \\
0\end{array}$ & 0.07 & 0.5 & 0.05 & -0.02 \\
\hline & & $c$ & $\begin{array}{l}58.5 \\
58.8\end{array}$ & $\begin{array}{l}1.17 \\
1.18\end{array}$ & $\begin{array}{c}0 \\
-0.01\end{array}$ & & 4.0 & 0.08 & +0.01 \\
\hline
\end{tabular}

Remarks :

Samples of No. 1, 2: $1.0 \mathrm{~g} \rightarrow 200 \mathrm{cc} \rightarrow 50 \mathrm{cc}$

Samples of No. $3\left\{\begin{array}{ll}\text { a, c } & 1.0 \mathrm{~g} \rightarrow 200 \mathrm{cc} \rightarrow 100 \mathrm{cc} \\ \mathrm{b} & 0.5 \mathrm{~g} \rightarrow 200 \mathrm{cc} \rightarrow 40 \mathrm{cc}\end{array}\right\}$ analysed 
以上の樣な結果で，第 5 法は第 $1 \sim 3$ 法に較べ稍々低 い值を示しているが，武料科量時及び測定日が異なるの で，試料の乾燥度合或は科量時の䛊差を考慮すれば，略 々一致している. 然し第 $1 \sim 3$ 法の溶液は鉄塩の存在か 有機物の混入により着色（赫褐色）していた。有僟物の 共存は, 溶液の粘度を增し, 炎光輝度を減少させる倾向 があるので, 有機物の多量に含有される倵料に就いては 第 $1 \sim 3$ 法は不適当であ各。

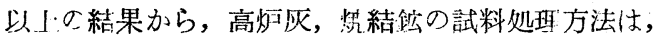
第 5 法が適当であると考え，その开現性，精度に就いて 検討を行つた。その結果は Table 10〜11の通りでま る.

以上の如く重量法と此较しても皇好な佂が得られ, 再 現性子よい. Table 11は試料の科取量或は分取量或は分 取量を桨えて精度を梌討したのであるが，カリウムの場 合には，非常に良好な結果を示した。しかしナトリウム の場合には，测定時の濃度が非常に低かつたので，周罒 の麇埃，污染された空気の影響等によりバラついたもの と思われる.従つてこの場命には高濃度のもので行えば な怙よい結果が得られたものと考える。

今迄行つてきた実験から判断すると，検出元素の濃度 は 20〜70 ppm. 程度のものが最も涀定し易く感じた。 低濃度部分では, 内部標淮用ダイアルの読みの誤差があ るので, 高い精度は望めない。蜜ろこの場合には直接強 度法の方がよいと思われた。

\section{3. 酸に不溶解の試料処理方法の検刢}

耐火材其の他酸に不溶解の武料については, 武料処理 方法として, 非酸酼酸法・ローレンススミス法の 2 法に ついて行つてみた。

試料は米国標蕉試料の粘土（K=0.45\%， $\mathrm{Na}=0.24$ \%)を伐用して行い，その結果は Table 12 の通りであ る.

上記の如く, $\mathrm{HF}+\mathrm{H}_{2} \mathrm{SO}_{4}$ 法は非常な低值を示し且バ ラッイた・高涬処理の際にも経験したのであるが，てれ は分解不宽全のためるまろうが, 遊雄の硫酸の残存量に
Table 12 Determination of alkalies in clay.

\begin{tabular}{c|c|c}
\hline & $\mathrm{K} \%$ & $\mathrm{Na} \%$ \\
\hline \multirow{3}{*}{$\mathrm{HF}+\mathrm{H}_{2} \mathrm{SO}_{4}$} & 0.12 & 0.05 \\
method & 0.14 & 0.06 \\
& 0.16 & 0.04 \\
& 0.27 & \\
\hline \multirow{2}{*}{ Lawrence- } & 0.46 & - \\
Smith & 0.46 & - \\
method & 0.45 & - \\
\hline
\end{tabular}

より炎光輝度の淢少が起つたためと思われる。

ローレンススミス法は，カリウムの場合は良好な結果 が得られたが，ナトリウムの場合は高濃度のカルシウム のため干渉されて泪定不能であつた。カルシウムを分離 した液について行えば良好な值が得られると思う。

\section{5. パーキンエルマー52-C型とランゲ式フレー ムホトメーターによる定量結果の比較}

東京工業試験所に於いて, 炎法の検討を実施しつつ, 作業分析に店用している間に，日本鋼管株式会社にラン ゲ式のフレームホトメーターが購入されたので，とれを

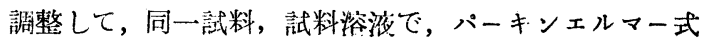
とランゲ式による定量結果を此较した。

向ランゲ式の炎光分析の条件は次の如くである。

Table 13 Flame photometric condition for Langes instrument

\begin{tabular}{c|c|c|c|c}
\hline & Filter & $\begin{array}{r}\text { Town- } \\
\text { gas }\end{array}$ & $\begin{array}{l}\text { Air } \\
\text { pressure }\end{array}$ & $\begin{array}{r}\text { Working } \\
\text { curve }\end{array}$ \\
\hline$K$ & $770.5 \mathrm{~m} \mu$ & $90 \mathrm{~mm}$ & 0.4 atm & $\begin{array}{c}0 \sim 100 \\
\text { p.p.m }\end{array}$ \\
\hline $\mathrm{Na}$ & $589.0 \mathrm{~m} \mu$ & $88 \mathrm{~mm}$ & $0.4 \mathrm{~atm}$ & $\begin{array}{c}0 \sim 50 \\
\text { p.p.m }\end{array}$ \\
\hline
\end{tabular}

ランゲ式フレームホトメーターは太部標準法で行う事 は不適当でまるので，Table 14 は操作の簡易の预から いずれも直接独度法で測定した結果である。

Table 14 Comparicon of results by Perkin-Elmer Model 52-C and Lange's flame photometer.

\begin{tabular}{|c|c|c|c|c|c|c|c|c|}
\hline \multirow{2}{*}{ Sample } & \multicolumn{4}{|c|}{$\mathrm{K}$} & \multicolumn{4}{|c|}{$\mathrm{Na}$} \\
\hline & Perkin & Lange & Deviation & $\begin{array}{c}\% \\
\text { Deviation }\end{array}$ & Perkin & Lange & Deviation & $\begin{array}{c}\% \\
\text { Deviation }\end{array}$ \\
\hline 1 & 5.05 & 4.96 & -0.09 & 1.80 & 0.10 & 0.09 & -0.01 & 10.0 \\
\hline 2 & 5.40 & 5.24 & -0.16 & 3.0 & 0.13 & 0.12 & -0.01 & 7.7 \\
\hline 3 & 5.30 & 5.01 & -0.29 & 5.5 & 0.05 & 0.03 & -0.02 & 40.0 \\
\hline 4 & 5.23 & 5.16 & -0.07 & 1.3 & 0.09 & 0.09 & 0 & 0 \\
\hline
\end{tabular}


分 光研 究 第 4 巻・第 3 号 (1956)

\begin{tabular}{|c|c|c|c|c|c|c|c|c|}
\hline 5 & 5.23 & 5.01 & -0.22 & 4.2 & 0.18 & 0.15 & -0.03 & 16.7 \\
\hline 6 & 5.13 & 4.80 & -0.33 & 6.4 & 0.08 & 0.08 & 0 & 0 \\
\hline 7 & 5.16 & 5.06 & -0.10 & 1.9 & 0.09 & 0.08 & -0.01 & 11.1 \\
\hline 8 & 6.60 & 6.61 & +0.01 & 0.1 & 0.21 & 0.23 & +0.02 & 9.5 \\
\hline 9 & 7.05 & 6.85 & -0.20 & 2.8 & 0.25 & 0.22 & -0.03 & 12.0 \\
\hline 10 & 6.05 & 5.82 & -0.23 & 3.8 & 0.23 & 0.23 & 0 & 0 \\
\hline 11 & 7.60 & 7.50 & -0.10 & 1.3 & 0.16 & 0.15 & -0.01 & 6.3 \\
\hline 12 & 7.30 & 7.35 & +0.05 & 0.7 & 0.15 & 0.12 & -0.03 & 20.0 \\
\hline 13 & 6.95 & 6.75 & -0.20 & 2.9 & 0.10 & 0.11 & +0.01 & 10.0 \\
\hline 14 & 7.00 & 7.10 & +0.10 & 1.4 & 0.16 & 0.16 & 0 & 0 \\
\hline 15 & 7.25 & 7.10 & -0.15 & 2.0 & 0.19 & 0.20 & +0.01 & 5.0 \\
\hline 16 & 6.95 & 6.75 & -0.20 & 2.9 & & & & \\
\hline 17 & 5.15 & 5.10 & -0.05 & 1.0 & & & & \\
\hline 18 & 5.00 & 5.00 & 0 & 0 & & & & \\
\hline 19 & 6.90 & 6.90 & 0 & 0 & & & & \\
\hline 20 & 6.85 & 6.70 & -0.15 & 2.2 & & & & \\
\hline 21 & 2.18 & 2.05 & -0.13 & 9.0 & & & & \\
\hline 22 & 2.36 & 2.28 & -0.08 & 3.4 & & & & \\
\hline 23 & 1.15 & 1.10 & -0.05 & 4.3 & & & & \\
\hline 24 & 1.70 & 1.80 & -0.10 & 5.9 & & & & \\
\hline 25 & 1.90 & 2.03 & +0.13 & 5.7 & & & & \\
\hline \multicolumn{4}{|c|}{ Meam deviation } & 2.82 & & & & \\
\hline
\end{tabular}

ランゲ式は市ガスを然料として使用したが，そのガス の安定する時間が一日の中でる限られている等の不便る あり，パーキン式の結果と此較してて稍々低目ではあるが 然し検淮子少量です夕, 伦険性す少いから, 日常の作業 分析面には充分価值あるるのと認められる。

\section{6. 結言}

以上の実験は，早急な解決を要望されたので検討期間
が短いため, 完全なるのとは言い難いが，一般に酸で溶 解する試料では第 5 法の処理方法をるつてすれば，従来 行われていた重量法に比較して，操作は迅速簡単であり 倜人誤差も少く, 精度も非常に良い。

古本実験は，1954年 6 月より約 1 ク月間に，種々の基 礎実験を㭘討しつつ，実際試料を分析したのであるが， 其の処理件数は 2 人の分析者で 700 件以上の多きに達し た。 